\title{
ENI DE MESQUITA SAMARA E A PESQUISA HISTÓRICA'
}

\author{
Horacio Gutiérrez
}

Universidade de São Paulo

Eni de Mesquita Samara foi uma historiadora de corpo e alma. Meu conhecimento de seu trabalho remonta à década de 1980, quando eu realizava minha dissertação de mestrado e participava no Seminário de História da Família, uma instância de debates com apresentação de textos que ela dirigia com Iraci Costa, professora da Faculdade de Economia da USP. Posteriormente, na década de 1990, tive o privilégio de ser seu aluno de doutorado, além de seu colaborador no Centro de Estudos de Demografia Histórica da América Latina (CEDHAL) e, finalmente, nos anos 2000, pude compartilhar de seu convívio como colega no Departamento de História da USP. Interessava-se por temas que a mim também cativaram, e chegamos inclusive a escrever textos em coautoria. Contudo, mais do que as lembranças do convívio universitário, ou o depoimento sobre a influência que ela exercera em mim, gostaria de fazer uma brevíssima reflexão a respeito da importância de seu trabalho de pesquisadora, particularmente em duas áreas da História com as quais sempre se identificou: a história demográfica e a história econômica.

A dimensão da atividade acadêmica de Eni foi plural e abrangeu a pesquisa histórica com fontes manuscritas desde os inícios, mas também, de modo continuado, incluiu a docência, orientação de alunos, extensão e atuações marcantes em sociedades científicas e no âmbito da gestão universitária. Centramo-nos aqui apenas em sua contribuição como historiadora e, em particular, em um aspecto notório,

Texto lido em evento realizado no Departamento de História da Universidade de São Paulo em abril de 2012, em homenagem à professora Eni de Mesquita Samara. 
conforme julgamos: sua relação com a história demográfica, a história econômica e as metodologias escolhidas para aproximar ambas as áreas e delas se aproximar.

Olhando sua produção acadêmica numa visão de conjunto, veem-se alguns eixos temáticos ou áreas de interesse que emergem de modo recorrente: os excluídos, as minorias, as populações subalternas, como mulheres, escravos, agregados, e sua relação com os grupos de poder. A intenção dessas pesquisas foi dar visibilidade a segmentos pouco valorizados pela historiografia anterior, mas também entender seu papel nos processos econômicos e sociais, resgatando historiograficamente, quando pertinente, o seu protagonismo nesses processos. $\mathrm{O}$ foco ao estudar as populações esquecidas tencionou revelar suas práticas familiares, relações de parentesco formais e informais, inserção nos espaços econômicos locais e regionais; descobrir as estratégias de sobrevivência criadas por esses segmentos, confrontando os resultados com as explicações derivadas de modelos analíticos usualmente empregados pela historiografia tradicional, para então desconstruir generalizações feitas indevidamente, a seu ver, por essa historiografia. Os períodos preferidos em suas pesquisas foram os séculos XVII, XVIII e XIX, analisando diversas regiões do Brasil, particularmente a capitania e província de São Paulo, recortes presentes em sua dissertação de mestrado (defendida em 1975) e em sua tese de doutorado (1980). Mas conforme avançava em suas pesquisas, o espaço de análise abriu-se para a América Latina como um todo, de cuja historiografia incorporou hipóteses, temas e fontes, estabelecendo um diálogo que manteria até o final.

A história econômica deve a Eni o exame minucioso de temas como a produção e circulação da riqueza colonial entre as diversas camadas sociais e, através dela, o desvendamento de estruturas de poder e de sujeição; a participação feminina nos mercados de trabalho e a conquista gradual do espaço público pelas mulheres, pontuando, entretanto, as diferenças de classe social existentes no mundo das mulheres, fazendo com que seus ideários variassem e até pudessem se chocar entre si. Atenção particular mereceu também de Eni o estudo das heranças e partilhas de bens e seu papel econômico na chefia de domicílios e na autonomia que ela permitira, em muitos casos, às proprietárias viúvas ao longo da história.

Com relação à história demográfica, outra de suas áreas favoritas de pesquisa, seu papel foi pioneiro, fazendo parte de um potente grupo de pesquisadores que na década de 1980 consolidou a história da população no Brasil. A intenção dessas pesquisas foi buscar padrões de comportamento, regularidades que permitissem compreender a formação, evolução e significado das estruturas demográficas e econômicas de sociedades do passado. Cabe aqui, sob essa perspectiva, lembrar 
seus trabalhos baseados em inventários e testamentos, com a finalidade central de identificar estratificações sociais e sua mudança no tempo, mas igualmente para reconstituir perfis biográficos exemplares. $\mathrm{O}$ foco demográfico guiou-a também em direção a estudos sobre migrações nacionais e internacionais, e por essa via a busca de padrões e rotas de assentamento das populações selecionadas. Mas seguramente o ponto alto de seus trabalhos demográficos refere-se à análise de estruturas familiares e domiciliares, levantando nesse campo novas evidências e construindo novas interpretações, como por exemplo, o predomínio da família nuclear no universo colonial paulista. A perspectiva demográfica foi, no entanto, muito além: permitiu a Eni adentrar em cheio no mundo das famílias e das mulheres, desvendando as estratégias presentes no casamento e no celibato, examinando os divórcios e as separações, os mecanismos de sustento familiar assim como o de preservação dos patrimônios, os preconceitos contra a mulher trabalhadora e a sua luta pela cidadania; enfim, permitindo conhecer as mentalidades e os valores dominantes em sociedades arraigadamente patriarcais e machistas, e com ampla influência, na esfera privada e pública, da Igreja Católica.

Como Eni conciliou suas pesquisas econômicas e demográficas, como as enlaçou? Além de buscar enfrentá-las com preocupações teóricas compatíveis, a nosso ver há um nexo não menos relevante, e diz respeito ao uso de metodologias quantitativas. Seu gosto para lidar com fontes primárias passíveis de quantificação, assim como sua desenvoltura para adotar, na interpretação dos dados, indicadores e métodos retirados da economia e da estatística descritiva, permitiram a Eni transitar com bastante desembaraço tanto pela história demográfica como pela econômica. Isto, ressalte-se, numa conjuntura como a das décadas de 1970 e 1980 , quando tais metodologias apenas emergiam e eram, por isso mesmo, muito debatidas ou, mais ainda, questionadas em sua legitimidade para ser aplicadas à pesquisa histórica. Essa forma de fazer história, no entanto, consolidou-se, naturalizando-se e se tornando rotina bem sucedida. Historiadores das gerações seguintes, entre os quais me incluo, usam agora a quantificação livremente, sem ter que pedir desculpas. Muito disso deve ser creditado às pesquisas pioneiras, como as de Eni e sua geração. Assim, seu pioneirismo e suas contribuições não se restringem apenas aos estudos de gênero - importantíssimos - ou à história da família-valiosíssima-, mas também, em nossa opinião, às metodologias utilizadas. 